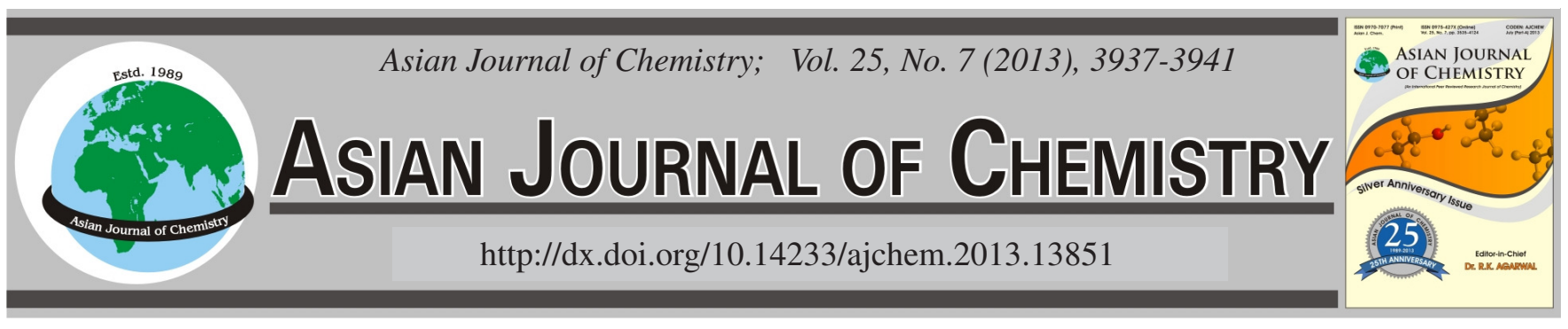

\title{
Antioxidant Activity of Consecutive Extracts of the Base, Stem and Leaves of Etlingera brevilabrum
}

\author{
B. MAHDAVI ${ }^{1, *}$, W.A. YAACOB ${ }^{2}$, LAILY B. Din ${ }^{2, *}$ and H. JAHANGIRIAN ${ }^{3}$
}

\begin{abstract}
${ }^{1}$ Department of Chemistry, Faculty of Science, Hakim Sabzevari University, P.O. Box 397, Sabzevar, Iran
${ }^{2}$ School of Chemical Sciences and Food Technology, Faculty of Science and Technology, Universiti Kebangsaan Malaysia, 43600 Bangi, Selangor, Malaysia

${ }^{3}$ Department of Chemistry, Faculty of Science, Universiti Putra Malaysia, 43400 Serdang, Selangor, Malaysia
\end{abstract}

*Corresponding author: Fax: +60 3 89214701; Tel: +60 3 89214700; E-mail: lbdin@ukm.my; behnammahdavi@yahoo.com

\begin{abstract}
The base, stem and leaves of Etlingera brevilabrum were extracted consecutively with hexane, ethyl acetate, acetone, methanol, methanol:water (1:1) and water and also solely with ethanol. The total phenolic content and antioxidant assays of DPPH radical scavenging activity, $\beta$-carotene bleaching, ferrous ion chelating ability and reducing power were carried out on the extracts. In most of the assays, the leaf extracts showed more activity than the others. The methanolic extract of leaf showed the highest total phenolic content and inhibition of $\beta$-carotene bleaching. The methanol:water extract of the leaf exhibited maximum DPPH radical scavenging and reducing power activity. However, the base methanolic extract showed the highest ferrous ion chelating ability, even higher than the positive controls of ascorbic acid and citric acid. All the extracts gave good linear correlations between total phenolic content and radical scavenging activity as well as between total phenolic content and reducing power.
\end{abstract}

Key Words: Etlingera brevilabrum, Antioxidant, Radical scavenging activity, Total phenolic content, $\beta$-Carotene bleaching, Metal chelating.

\section{INTRODUCTION}

The plants of Zingiberaceae are widely distributed in Southeast Asia ${ }^{1}$. Etlingera is one of the tallest genus of the family and can grow up to $6 \mathrm{~m} \mathrm{high}^{2}$. In tropical areas, the Etlingera species have different traditional and commercial uses. Fruits, flowers and young shoots are used as condiment ${ }^{3,4}$. Different parts of Etlingera brevilabrum have various usage in which the base is used as medicine for stomach-ache, the sap from the stem is used as drops to cure eyes, the leaves are used to treat dry skin on the legs and roasted leaves are rubbed on the bodies of children to treat long-lasting fever 5 .

Due to the wide variety of uses of Zingiberaceae plants as a spice, condiment and traditional medicine, many research groups have concentrated their studies on the antioxidant activity of various species of the family. Chan et al. ${ }^{6}$ studied the total phenolic content and FIC ability of 26 Zingiberaceae species including five Etlingera species of E, elatior, $E$. rubrostriata, E. littoralis, E. fulgens, E. maingayi. Among the 26 species, the leaves of Etlingera species exhibited the highest total phenolic contents and radical scavenging activity. The leaves of Alpinia galanga and E. maingayi exhibited the highest ferrous ion chelating ability ${ }^{6}$. The total phenolic contents, radical scavenging activity and $\beta$-carotene bleaching assay of the flower and seed of Alpina zerumbet were evaluated by Elzaawely. The results of the study indicated a higher total phenolic contents in the flower, higher $\beta$-carotene bleaching assay activity for the seed and the same radical scavenging activity for the flower and the seed. El-Ghorb et al. ${ }^{8}$ measured the total phenolic contents, radical scavenging activity and reducing power of Zingiber officinale and Cuminum cyminum rhizome for all the assays, in which $Z$. officinale showed the highest amount and activity.

The objectives of present study were to determine the total phenolic content and antioxidant activity of consecutive extracts of ethyl acetate, acetone, methanol, methanol:water (1:1) and water from the base, stem and leaves of Etlingera brevilabrum plus their ethanolic extracts, by antioxidant assays such as DPPH free radical scavenging, $\beta$-carotene bleaching, metal chelating ability and reducing power. Notably, there is no previous report on the antioxidant activity E. brevilabrum in the literature.

\section{EXPERIMENTAL}

1,1-Diphenyl-2-picrylhydrazyl (DPPH), $\alpha$-tocopherol, 3-(2-pyridyl)-5,6-bis(4-phenylsulfonic acid)-1,2,4-triazine 
(ferrozine), $\beta$-carotene, polyoxyethylene sorbitan monopalmitate (Tween 40) and butylated hydroxytoluene (BHT) were purchased from Sigma; ascorbic acid (AscA), citric acid (CitA) and EDTA from Merck; $\mathrm{K}_{3} \mathrm{Fe}(\mathrm{CN})_{6}, \mathrm{Na}_{2} \mathrm{CO}_{3}, \mathrm{FeSO}_{4} \cdot 7 \mathrm{H}_{2} \mathrm{O}, \mathrm{KH}_{2} \mathrm{PO}_{4}$ and $\mathrm{K}_{2} \mathrm{HPO}_{4}$ from $\mathrm{BDH}$; linoleic acid and Folin-Ciocalteu's reagent (FCR) from Fluka; tricholoroacetic acid (TCA) from Unilab; gallic acid (GA) from Acros; and all solvents of analytical grade were obtained from Systerm.

The plant parts of Etlingera brevilabrum including the base, stem and leaves were collected in December 2009 from its natural habitat in Sabah, Malaysia. A voucher specimen of WYA 386 for the plant was deposited at the Universiti Kebangsaan Malaysia Herbarium (HUKMB). The plant species were identified by a botanist, Mr. Sani Miran, of Universiti Kebangsaan Malaysia.

Plant extracts: The dried parts of Etlingera brevilabrum were ground and extracted consecutively with increasing polarity solvents of hexane to ethyl acetate to acetone to methanol to methanol:water (1:1) and lastly to hot water. For series of hexane, ethyl acetate, acetone and methanol, the samples were macerated for $72 \mathrm{~h}$ at room temperature. After each filtration, the same fresh solvent was added to the remaining sample and left to stand for the next $24 \mathrm{~h}$, followed by another filtration. This portion was combined accordingly with that of the $72 \mathrm{~h}$ and then methanol:water (1:1) for $12 \mathrm{~h}$ and finally hot water for $1 \mathrm{~h}$ were employed. The solvents were evaporated under reduced pressure using Heidolph evaporator (Laborota 4000 eco). The extracts containing water were frozen dried. For separate extraction with ethanol, each sample was macerated for $72 \mathrm{~h}$.

Determination of total phenolic content (TPC): The total phenolic content of the extracts was measured according to Folin-Ciocalteu's reagent method described by Liu et al. ${ }^{9}$ and Xu et al. ${ }^{10}$ with some modification. Briefly, a $0.5 \mathrm{~mL}$ of FCR (10\% in distilled water) was added to a vial containing $0.5 \mathrm{~mL}$ of each extract $(1000 \mu \mathrm{g} / \mathrm{mL}$ in methanol $)$ and $1.5 \mathrm{~mL}$ of distilled water. The mixture was vigorously shaken. After 5 min, $2 \mathrm{~mL}$ of $10 \%$ sodium carbonate solution was added and the mixture was shaken again. The mixtures incubated in the dark for $2 \mathrm{~h}$ at room temperature. The absorbance was measured at $760 \mathrm{~nm}$ with the Varian (Cary 50 conc) UV-VIS spectrophotometer. The analyses were carried out in triplicate. A standard curve of gallic acid was used for determination of total phenlic content in the oils from which the total phenlic content was estimated as gallic acid equivalent (GAE), that is, $\mathrm{mg}$ of gallic acid per gram of extract.

Determination of radical scavenging activity (RSA): The redical scavenging activity of the extracts was measured according to the method reported previously with some modification $^{11,12}$. Briefly, a $1.5 \mathrm{~mL}$ aliquot of each extract in methanol at $20,100,500$ and $1000 \mu \mathrm{g} / \mathrm{mL}$ was added to $1 \mathrm{~mL}$ of 0.1 $\mathrm{mM}$ DPPH in methanol. The mixture was shaken for $1 \mathrm{~min}$ and allowed to stand in the dark for $90 \mathrm{~min}$ at room temperature; the absorbance was read at $517 \mathrm{~nm}$. Positive controls of ascorbic acid, butylated hydroxy toluene, gallic acid and $\alpha$-tocpherol were used. All measurements were carried out in triplicate on 3 days. Using the following equation, the radical scavenging activity (RSA) was calculated:

$$
\operatorname{RSA}(\%)=\left[\frac{\left(\mathrm{A}_{\mathrm{c}}-\mathrm{A}_{\mathrm{s}}\right)}{\mathrm{A}_{\mathrm{c}}}\right] \times 100
$$

where $\mathrm{A}_{\mathrm{c}}$ is the absorbance of the control (DPPH solution without extract) and $A_{s}$ is the absorbance of the extract (extract with DPPH solution).

Determination of antioxidant activity with the $\beta$-carotene bleaching assay (BCB): The antioxidant activity of the extracts using $\beta$-carotene-linoleic acid was measured according to the literature reports with some modification ${ }^{13,14}$. Briefly, $5 \mathrm{~mL}$ of $\beta$-carotene solution in chloroform $(1 \mathrm{mg} / \mathrm{mL})$ was added to a flask containing $50 \mu \mathrm{L}$ of linoleic acid and $500 \mu \mathrm{L}$ of Tween 40. The chloroform was evaporated under vacuum at $45{ }^{\circ} \mathrm{C}$ for $10 \mathrm{~min}$, then $125 \mathrm{~mL}$ of oxygenated water was added and the mixture was vigorously shaken to form an emulsion. Then, $2.5 \mathrm{~mL}$ of the emulsion was added to a $0.2 \mathrm{~mL}$ of extract solution $(1000 \mu \mathrm{g} / \mathrm{mL}$ in methanol $)$ and the absorbance was immediately read at $470 \mathrm{~nm}$. The mixtures incubated at $50{ }^{\circ} \mathrm{C}$ and the absorbance was measured at 45 min intervals up to $180 \mathrm{~min}$. All measurements were carried out in triplicate. Using the following formula, the antioxidant activity (AA) was evaluated in terms of bleaching of $\beta$-carotene:

$$
\mathrm{AA}(\%)=\left[\frac{1-\left(\mathrm{A}_{0}^{\mathrm{s}}-\mathrm{A}_{\mathrm{t}}^{\mathrm{s}}\right.}{\left(\mathrm{A}_{0}^{\mathrm{c}}-\mathrm{A}_{\mathrm{t}}^{\mathrm{c}}\right.}\right] \times 100
$$

where $\mathrm{A}_{0}^{\mathrm{s}}$ and $\mathrm{A}_{0}^{\mathrm{c}}$ are absorbance of the extract and control ( $2.5 \mathrm{~mL}$ of the emulsion and $0.2 \mathrm{~mL}$ of methanol) at zero time, $\mathrm{A}_{\mathrm{t}}^{\mathrm{s}}$ and $\mathrm{A}_{\mathrm{t}}^{\mathrm{c}}$ are absorbance of the extract and control after $180 \mathrm{~min}$.

Ferrous ion chelating ability (FIC assay): The chelating of $\mathrm{Fe}^{2+}$ (FIC) by the extracts was estimated with the method previously carried out by Chan et al. ${ }^{3}$ and Singh and Rajini ${ }^{15}$. A $50 \mu \mathrm{L} \mathrm{FeSO}_{4}(2 \mathrm{mM})$ was added to a vial containing $1 \mathrm{~mL}$ of each extract in methanol at $2000 \mu \mathrm{g} / \mathrm{mL}$ and $2 \mathrm{~mL}$ of distilled water. The reaction was initiated by addition of $100 \mu \mathrm{L}$ of ferrozine $(5 \mathrm{mM})$; the reaction mixture was shaken well and incubated at room temperature for $10 \mathrm{~min}$. The absorbance was measured at $562 \mathrm{~nm}$. All measurements were run in triplicate. Positive controls of EDTA, citric acid and ascorbic acid were used. The percentage of inhibition of ferrozine- $\mathrm{Fe}^{2+}$ complex formation was calculated using the following equation:

$$
\text { Inhibiton }(\%)=\left[\frac{\left(\mathrm{A}_{\mathrm{s}}-\mathrm{A}_{\mathrm{s}}\right)}{\mathrm{A}_{\mathrm{c}}}\right] \times 100
$$

where $A_{c}$ is the absorbance of the control (contains $50 \mu \mathrm{L}$ of the $\mathrm{FeSO}_{4}, 100 \mu \mathrm{L}$ of the ferrozine and $1 \mathrm{~mL}$ of methanol) and $\mathrm{A}_{\mathrm{s}}$ is the absorbance of the extract.

Reducing power assay (RP assay): The reducing power activity (RP) of the extracts was carried out by reduction of $\mathrm{Fe}^{3+}$ to $\mathrm{Fe}^{2+}$ method as described previously ${ }^{16,17}$. A $1 \mathrm{~mL}$ of each extract in methanol at $2000 \mu \mathrm{g} / \mathrm{mL}$ was mixed with $2.5 \mathrm{~mL}$ of phosphate buffer (0.2 M, pH 6.6) and $2.5 \mathrm{~mL}$ of $\mathrm{K}_{3}\left[\mathrm{Fe}(\mathrm{CN})_{6}\right]$ $1 \%$; the mixture was incubated at $50{ }^{\circ} \mathrm{C}$ for $0.5 \mathrm{~h}$. Then 2.5 $\mathrm{mL}$ of $10 \%$ trichloroacetic acid was added and the mixture was centrifuged at $3000 \mathrm{rpm}$ for $10 \mathrm{~min}$ (Kubota 2420). Finally, $1 \mathrm{~mL}$ of the supernatant solution was mixed with $1 \mathrm{~mL}$ of distilled water and $0.2 \mathrm{~mL}$ of $0.1 \% \mathrm{FeCl}_{3}$; then the absorbance was measured at $700 \mathrm{~nm}$. Positive controls of ascorbic acid, 
$\alpha$-tocopherol and BHT were used. All measurements were run in triplicate; higher absorbance of the reaction mixture indicated increasing in reducing power.

Statistical analysis: All data are mean \pm SD of nine parallel measurements for DPPH radical scavenging and three parallel measurements for the other assays. The SPSS Statistics 18 software was used for variance analysis (ANOVA) and Duncan's test to check for the difference between various extracts from each part and for correlation analysis of total phenolic content versus radical scavenging activity and reducing power ability; significance of difference was determined at the $5 \%$ level $(p<0.05)$.

\section{RESULTS AND DISCUSSION}

Total phenolic content: Various phenolic compounds such as simple phenols, phenolic acids, flavonoids and hydroxycinnamic acid derivatives that are found in the plant kingdom show strong antioxidant activity which depends on their concentration ${ }^{18-21}$. Total phenolic compounds play an effective role in stabilizing lipid peroxidation ${ }^{22}$. According to the results of total phenolic content for different extracts of Etlingera brevilabrum, as shown in Table-1, the stem extracts of any similar solvent exhibited less phenolic content than that of the base and leaf extracts and the leaf extracts had the highest total phenolic content. Within each plant part extract, BEa, SA and LM gave the highest phenolic content of $31.81 \pm 1.24$, $17.52 \pm 0.98$ and $57.74 \pm 1.59 \mathrm{mg} \mathrm{GAE} / \mathrm{g}$ (that is equivalent $\mathrm{mg}$ of gallic acid per gram of extract). Although it was expected that water and methanol:water (1:1) extracts contain many more phenolic compounds, because of their polarity, the BW and BMW were the lowest two in TPC $0.92 \pm 0.30$ and $1.96 \pm$ $0.42 \mathrm{mg} \mathrm{GAE} / \mathrm{g}$, respectively. The lowest and the highest polarity stem extracts have lower TPC's of $1.97 \pm 0.61$ (SEa) and $4.82 \pm 1.27 \mathrm{mg} \mathrm{GAE} / \mathrm{g}(\mathrm{SW})$. Among the leaf extracts, the LEa has the lowest TPC $(17.10 \pm 1.21 \mathrm{mg} \mathrm{GAE} / \mathrm{g})$. Methanolic leaf extract of E. brevilabrum in this study showed higher TPC ( $57.74 \pm 1.59 \mathrm{mg} \mathrm{GAE} / \mathrm{g})$ than that of E. fulgens, E. littoralis, E. rubrostriata and E. elatior at 25.40, 28.10, 34.80 and $35.50 \mathrm{mg} \mathrm{GAE} / \mathrm{g}^{4,23}$. However, the TPC of the leaves of E. elatior from Indonesia was $0.81 \pm 0.10 \mathrm{mg} \mathrm{GAE} / \mathrm{g}^{24}$.

Radical scavenging activity: DPPH is a stable nitrogencentered radical, which, in the presence of hydrogen or electron donor compounds becomes a stable diamagnetic molecule and loses its violet colour ${ }^{25,26}$. Because of high reproducibility and commercial availability in comparison with other radical scavenging compounds, such as 2,2'-azinobis-3-ethylbenzothiazoline-6-sulfonic acid (ABTS) and N,N-dimethyl- $p$ phenylenediamine (DMPD), the DPPH scavenging is a well known and conventional method in natural antioxidant studies $^{27,28}$. According to the results of DPPH radical scavenging activity (RSA) in Table-1, for the base extracts, BEa showed the lowest $\mathrm{IC}_{50}(209.54 \pm 6.39 \mu \mathrm{g} / \mathrm{mL})$ compared with other extracts. Among stem and leaf extracts, SMW and LMW showed the lowest $\mathrm{IC}_{50}(506.67 \pm 5.29$ and $191.39 \pm 5.93 \mu \mathrm{g} / \mathrm{mL})$.

TABLE-1

TOTAL PHENOLIC CONTENT (TPC), DPPH RADICAL SCAVENGING ACTIVITY (RSA), $\beta$-CAROTENE BLEACHING (BCB), FERROUS ION CHELATING ABILITY (FIC), AND REDUCING POWER ABILITY (RP) OF CONSECUTIVE EXTRACTS OF THE BASE (B), STEM (S), AND LEAVES (L) OF Etlingera brevilabrum OBTAINED BY USING Ea (ETHYL ACETATE), A (ACETONE), M (METHANOL), MW (METHANOL:WATER 1:1), W (WATER), AND Et (ETHANOL)

\begin{tabular}{|c|c|c|c|c|c|}
\hline Extract & TPC mg GAE/g extract & $\operatorname{RSA} \operatorname{IC}_{50}(\mu \mathrm{g} / \mathrm{mL})$ & $\mathrm{BCB}(\%)$ & FIC $(\%)$ & RP mg AscAE/g extract \\
\hline \multicolumn{6}{|c|}{ Base } \\
\hline $\mathrm{BEa}$ & $31.81 \pm 1.24 \mathrm{a}^{*}$ & $209.54 \pm 6.39 a$ & $71.02 \pm 3.42 \mathrm{a}$ & $69.69 \pm 0.48 d$ & $11.27 \pm 0.84 b$ \\
\hline BA & $30.61 \pm 2.18 \mathrm{a}$ & $444.10 \pm 5.12 d$ & $40.25 \pm 4.48 \mathrm{e}$ & $17.49 \pm 2.45 \mathrm{e}$ & $6.60 \pm 0.65 d$ \\
\hline $\mathrm{BM}$ & $23.39 \pm 0.76 b$ & $414.10 \pm 7.95 \mathrm{e}$ & $55.49 \pm 3.05 \mathrm{~cd}$ & $97.17 \pm 1.85 \mathrm{a}$ & $46.89 \pm 1.28 \mathrm{a}$ \\
\hline BMW & $1.96 \pm 0.42 d$ & $377.67 \pm 9.62 b$ & $58.59 \pm 1.98 b c$ & $88.47 \pm 1.14 b$ & $6.91 \pm 0.73 d$ \\
\hline BW & $0.92 \pm 0.3 \mathrm{~d}$ & $607.64 \pm 10.39 f$ & $61.10 \pm 2.12 b$ & $80.11 \pm 1.76 c$ & $9.56 \pm 0.75 c$ \\
\hline BEt & $21.73 \pm 0.73 c$ & $392.76 \pm 3.87 \mathrm{c}$ & $54.00 \pm 2.90 \mathrm{~d}$ & $81.52 \pm 0.75 c$ & $4.56 \pm 0.65 \mathrm{e}$ \\
\hline \multicolumn{6}{|c|}{ Stem } \\
\hline SEa & $1.97 \pm 0.61 \mathrm{f}$ & $991.02 \pm 9.29 \mathrm{e}$ & $68.83 \pm 3.38 \mathrm{a}$ & $47.57 \pm 0.98 \mathrm{e}$ & $3.38 \pm 0.76 c$ \\
\hline SA & $17.52 \pm 0.98 a$ & $905.81 \pm 10.11 d$ & $55.20 \pm 2.33 b$ & $70.55 \pm 1.10 c$ & $6.43 \pm 0.86 a$ \\
\hline SM & $14.38 \pm 0.71 b$ & $522.79 \pm 6.73 b$ & $49.34 \pm 5.08 c$ & $61.26 \pm 1.69 d$ & $5.59 \pm 0.87 b$ \\
\hline SMW & $10.00 \pm 0.57 d$ & $506.67 \pm 5.29 a$ & $55.93 \pm 3.40 b$ & $84.25 \pm 1.46 b$ & $6.99 \pm 0.58 \mathrm{a}$ \\
\hline SW & $4.82 \pm 1.27 \mathrm{e}$ & $782.23 \pm 5.98 c$ & $53.56 \pm 2.41 b$ & $89.45 \pm 1.01 \mathrm{a}$ & $4.95 \pm 0.54 b$ \\
\hline SEt & $12.82 \pm 0.36 \mathrm{c}$ & $524.91 \pm 3.34 b$ & $52.45 \pm 2.50 \mathrm{cb}$ & $90.63 \pm 1.46 \mathrm{a}$ & $3.13 \pm 0.42 c$ \\
\hline \multicolumn{6}{|c|}{ Leaf } \\
\hline LEa & $17.10 \pm 1.21 \mathrm{~d}$ & $551.48 \pm 7.22 \mathrm{f}$ & $59.79 \pm 4.92 \mathrm{c}$ & $51.29 \pm 0.81 b$ & $30.03 \pm 036 f$ \\
\hline LA & $23.83 \pm 1.98 \mathrm{~cd}$ & $442.50 \pm 6.93 d$ & $62.46 \pm 4.71 c$ & $49.44 \pm 1.68 \mathrm{c}$ & $19.75 \pm 1.19 \mathrm{~d}$ \\
\hline LM & $57.74 \pm 1.59 \mathrm{a}$ & $209.65 \pm 4.92 b$ & $77.29 \pm 1.49 a$ & $33.84 \pm 1.14 d$ & $105.23 \pm 2.48 c$ \\
\hline LMW & $45.63 \pm 1.77 b$ & $191.39 \pm 5.93 \mathrm{a}$ & $66.82 \pm 2.90 b$ & $81.22 \pm 0.57 a$ & $143.87 \pm 1.71 \mathrm{a}$ \\
\hline LW & $56.60 \pm 2.72 \mathrm{a}$ & $449.34 \pm 7.52 \mathrm{e}$ & $59.93 \pm 2.91 \mathrm{c}$ & $80.18 \pm 2.29 \mathrm{a}$ & $119.54 \pm 3.06 b$ \\
\hline LEt & $31.08 \pm 0.76 c$ & $264.29 \pm 6.36 c$ & $64.11 \pm 2.23 b c$ & $50.30 \pm 0.96 b c$ & $37.55 \pm 1.74 \mathrm{e}$ \\
\hline \multicolumn{6}{|c|}{ Standard } \\
\hline BHT & - & $14.36 \pm 1.25 \mathrm{c}$ & $71.99 \pm 4.44 \mathrm{~b}$ & - & - \\
\hline GA & - & $5.27 \pm 1.26 \mathrm{a}$ & $44.24 \pm 1.33 c$ & - & - \\
\hline Toc & - & $11.29 \pm 11.54 \mathrm{~b}$ & $87.90 \pm 2.53 a$ & - & - \\
\hline AscA & - & $45.74 \pm 2.60 \mathrm{~d}$ & $21.83 \pm 2.04 \mathrm{~d}$ & $13.44 \pm 0.36 c$ & - \\
\hline CitA & - & - & - & $22.03 \pm 0.75 b$ & - \\
\hline EDTA & - & - & - & $97.39 \pm 0.37 \mathrm{a}$ & - \\
\hline
\end{tabular}

*Values are presented as means \pm SD $(n=3)$. Means with different letters are significantly different in each column for any part and standards. 
The leaf extracts, except LEa exhibited more radical scavenging activity than the stem and base extracts. All positive controls showed higher radical scavenging activity than the extracts. According to the statistical analyses, there was no significant association between consecutive extracts from each part of $E$. brevilabrum.

Antioxidant activity (AA) with the $\boldsymbol{\beta}$-carotene bleaching: This method (BCB) is based on the fading of yellow colour of $\beta$-carotene in the presence of radicals formed from linoleic acid oxidation. The presence of other antioxidants reduces the rate of $\beta$-carotene bleaching ${ }^{29,30}$. The results of $\beta$-carotene bleaching of the extracts from different parts of E. brevilabrum are presented in Table-1. In this assay, the antioxidant activity for all extracts was stronger than those of the positive controls of ascorbic acid and gallic acid. For each part, the highest antioxidant activity was shown by $\mathrm{BEa}(71.02 \pm 3.42 \%)$, SEa $(68.83 \pm 3.38 \%)$ and $\mathrm{LM}(77.29 \pm 1.49 \%)$. The first two extracts of the lowest polarity ethyl acetate which were found to be the most active ones are in contrast to the polarity viewpoint. For each part, the least active extracts were BA (40.25\%), SM $(49.34 \%)$ and LW $(59.93 \pm 2.91 \%)$. Among the ethanolic extracts, LEt $(64.11 \pm 2.23 \%)$ showed the highest antioxidant activity, followed by BEt $(54.00 \pm 2.90 \%)$ and SEt $(52.45 \pm$ $2.50 \%$ )

Ferrous ion chelating ability: Low cost and high sensitivity make ferrozine a good spectrophotometric reagent for iron chelating $^{31}$. However, the presence of other chelating compounds would disrupt the complex formation and decrease the purple colour of the complex. The phenolic compounds and polysaccharides found in the plants can reduce the lipid peroxidation by stabilizing the oxidized form of metal ions ${ }^{32,33}$. As shown in Table-1, extracts of BM, SW and LMW $(97.17 \pm 1.85,89.45$ \pm 1.01 and $81.22 \pm 0.57 \%$, respectively) indicated the highest ferrous ion chelating for each part of E. brevilabrum. Among the three standards used in this assay, ascorbic acid and citric acid (CitA) with chelating ability of $13.44 \pm 0.36$ and $22.03 \pm$ $0.75 \%$ were found to be weak chelators for ferrous ion compared to all extracts except that of the BA $(17.49 \pm 2.45 \%)$, whereas EDTA showed the highest ability to chelate ferrous ions. The ethanolic extracts showed decreasing ability in the ferrous ion chelating ability from the stem to base to leaves. According to the results of previous study the leaves of the other Zingiberaceae species including Curcuma longa, Kaempferia galanga, Alpinia galanga, E. elatior, Zingiber spectabile and E. maingayi showed higher ferrous ion chelating ability than that of E. brevilabrum ${ }^{6}$.

Reducing power: According to Table-1, BEt had demonstrated the lowest reducing power of $4.56 \pm 0.65 \mathrm{mg} \mathrm{AscAE} / \mathrm{g}$ (that is equivalent $\mathrm{mg}$ of ascorbic acid per gram of extract) compared with the other base extracts; and BM, with $46.89 \pm$ $1.28 \mathrm{mg}$ AscE/g was recognized as the most active one. SMW $(6.99 \pm 0.58 \mathrm{mg} \mathrm{AscAE} / \mathrm{g})$ has higher RP than the other stem extracts. In general, all the leaf extracts have revealed more $\mathrm{RP}$ compared to the stem and base extracts. The most active leaf extract of E. brevilabrum was LMW with $143.87 \pm 1.71$ $\mathrm{mg}$ AscAE/g.

Total phenolic content-radical scavenging activity and total phenolic content-reducing power correlation: The present study demonstrated a good linear correlation between total phenolic content and radical scavenging activity similar to that reported in previous studies. Andarwulan reported a high correlation coefficient between total phenolic content and DPPH radical scavenging of extracts that were obtained from Etlingera Elatior ${ }^{24}$; Moyo et al ${ }^{18}$ for extracts of different parts of Sclerocary a birrea and Harpephyllum caffrum (Anacardiaceae); and Mohad-Esa et al..$^{34}$ for metanolic extracts of different parts from Hibiscus sabdariffa L.(Malvaeae) reported a positive correlation between total phenolic content and DPPH radical scavenging. The regression results (Table-2) for extracts from different parts of Etlingera brevilabrum at $1000 \mu \mathrm{g} / \mathrm{mL}$ showed the maximum correlation for BEa $(\mathrm{R}=0.98), \mathrm{SA}(\mathrm{R}=0.99)$ and $\mathrm{LW}(\mathrm{R}=0.99)$ and the minimum correlation for $\mathrm{BW}(\mathrm{R}=$ $0.82)$, SMW $(\mathrm{R}=0.78)$ and $\mathrm{LEa}(\mathrm{R}=0.87)$.

TABLE-2

REGRESSION RESULTS OF TOTAL PHENOLIC CONTENTDPPH RADICAL SCAVENGING ACTIVITY (TPC-RSA) AND TOTAL PHENOLIC CONTENT-REDUCING POWER ABILITY (TPC-RP) CORRELATION OF CONSECUTIVE EXTRACTS OF THE BASE (B), STEM (S), AND LEAVES (L) OF Etlingera brevilabrum OBTAINED BY USING Ea (ETHYL ACETATE), A (acetone), M (METHANOL), MW (METHANOL:WATER 1:1), W (WATER), AND Et (ETHANOL)

\begin{tabular}{ccccc} 
& \multicolumn{2}{c}{ TPC-RSA Correlation } & \multicolumn{2}{c}{ TPC-RP correlation } \\
\hline Base & $\mathrm{R}^{*}$ & SE** & $\mathrm{R}$ & $\mathrm{SE}$ \\
BEa & 0.98 & 0.28 & 0.83 & 0.37 \\
BA & 0.84 & 0.33 & 0.95 & 0.38 \\
BM & 0.98 & 0.17 & 0.89 & 0.38 \\
BMW & 0.92 & 0.18 & 0.96 & 0.13 \\
BW & 0.82 & 0.25 & 0.97 & 0.00 \\
BEt & 0.90 & 0.36 & 0.87 & 0.39 \\
\hline & & Stem & & \\
SEa & 0.84 & 0.43 & 0.98 & 0.11 \\
SA & 0.99 & 0.13 & 0.99 & 0.25 \\
SM & 0.95 & 0.25 & 0.93 & 0.13 \\
SMW & 0.78 & 0.40 & 0.80 & 0.19 \\
SW & 0.80 & 0.45 & 0.88 & 0.34 \\
SEt & 0.88 & 0.19 & 0.98 & 0.28 \\
\hline & & Leaf & & \\
LEa & 0.87 & 0.36 & 0.85 & 0.21 \\
LA & 0.93 & 0.43 & 0.97 & 0.51 \\
LM & 0.96 & 0.49 & 0.96 & 0.49 \\
LMW & 0.97 & 0.27 & 0.93 & 0.44 \\
LW & 0.99 & 0.31 & 0.95 & 0.35 \\
LEt & 0.95 & 0.27 & 0.96 & 0.22 \\
\hline
\end{tabular}

*R: Correlation coefficient; **SE: Standard error.

Previous studies demonstrated that there is a linear correlation between the total phenolic content and the reducing power activity of plant extracts; Hassas-Roudsari et al..$^{35}$ for ethanolic and water extracts of canola meal and also Moyo et $a l .{ }^{18}$ for extracts of $S$. birrea and $H$. caffrum reported the same results. The statistical results of extracts from three different parts of Etlingera brevilabrum showed the maximum correlation for BW $(\mathrm{R}=0.97), \mathrm{SA}(\mathrm{R}=0.986)$ and $\mathrm{LA}(\mathrm{R}=$ $0.99)$; and the minimum for $\mathrm{BEa}(\mathrm{R}=0.83)$, $\mathrm{SMW}(\mathrm{R}=0.80)$ and LEa $(\mathrm{R}=0.85)$. With these results, it could be said that a significant linear correlation exists between the total phenolic content and reducing power activity of extracts from three different parts of E. brevilabrum. 


\section{Conclusion}

The results of this study indicated that the consecutive extracts of the base, stem and leaves of Etlingera brevilabrum have different antioxidant activity. It can be concluded in most assays that, the leaf extracts were more active than the base and stem extracts. The methanolic leaf extract with $57.74 \mathrm{mg}$ GAE/g and 77.29\% showed the highest total phenolic content and $\beta$-carotene bleaching. The methanol:water leaf extract with $\mathrm{IC}_{50}=191.39 \mu \mathrm{g} / \mathrm{mL}$ and $143.87 \mathrm{mg}$ AscAE $/ \mathrm{g}$ exhibited the maximum DPPH radical scavenging activities and reducing power ability but methanolic base extract with $97.17 \%$ showed the highest metal chelating ability. This research also revealed that there are linear correlations between total phenolic content and radical scavenging ability and also total phenolic content and reducing power, which is in accordance with previous studies.

\section{ACKNOWLEDGEMENTS}

The authors thank the School of Chemical Sciences and Food Technology for technical assistance. Thanks are aslo due to the Ministry of Higher Education Malaysia and UKM for financial support through Research University Operation Fund UKM-OUP-KPB-31-156/2011 and Fundamental Research Grant Scheme UKM-ST-06-FRGS0110-2009.

\section{REFERENCES}

1. M. Habsah, M.Amran, M.M. Mackeen, N.H. Lajis, H. Kikuzaki, N. Nakatani, A.A. Rahman, Ghafar and A.M. Ali, J. Ethnopharmacol., 72, 403 (2000).

2. S.H. Khaw, Gardens' Bull. Singapore, 53, 191239 (2001).

3. E.W.C. Chan, Y.Y. Lim, S.K. Ling, S.P. Tan, K.K. Lim and M.G.H. Khoo, LWT-Food Sci. Technol., 42, 1026 (2009).

4. E.W.C. Chan, Y.Y. Lim and M. Omar, Food Chem., 104, 1586 (2007).

5. A.D. Poulsen, Etlingera of Borneo, Natural History Publications (Borneo) in Association with Royal Botanic Garden Edinburgh, edn. 1, p. 263 (2006)

6. E.W.C. Chan, Y.Y. Lim, L.F. Wong, F.S. Lianto, S.K. Wong, K.K. Lim, C.E. Joe and T.Y. Lim, Food Chem., 109, 477 (2008).

7. A.A. Elzaawely, T.D. Xuan and S.H. Koyamaand, Food Chem., 104, 1648 (2007).

8. A.H. El-Ghorab, M. Nauman, F.M. Anjum, S. Hussain and M. Nadeem, J. Agric. Food Chem., 58, 8231 (2010).
9. X. Liu, S. Ardo, M. Bunning, J. Parry, K. Zhou, C. Stushnoff, F. Stoniker, L. Yu and P. Kendall, LWT-Food Sci. Technol., 40, 552 (2007).

10. F. Xu, L. Li, X. Huang, H. Cheng, Y. Wang and H. Cheng, J. Med. Plants Res., 4, 2544 (2010).

11. G.C. Yen and H.Y. Chen, J. Agric. Food Chem., 43, 27 (1995).

12. A.A. Karagözler, E. Bengi, Y.E. Çalmaz and D.A.Uygun, Food Chem., 111, 400 (2008).

13. A. von Gadow, E. Joubert and C.F. Hansmann, J. Agric. Food Chem., 45, 632 (1997).

14. X.J. Duan, W.W. Zhang, X.M. Li and B.G. Wang, Food Chem., 95, 37 (2006).

15. N. Singh and P.S. Rajini, Food Chem., 85, 611 (2004).

16. M.H. Alma, A. Mavi, A. Yildirim, M. Digrak and T. Hirata, Biol. Pharm. Bull., 26, 1725 (2003).

17. H. Qi, X. Liu, J. Ma, Q, Zhang and Z. Li, J. Med. Plants Res., 4, 2445 (2010).

18. M. Moyo, A.R. Ndhlala, J.F. Finnie and J. Van Staden, Food Chem., 123, 69 (2010).

19. S. Serçe, M. Özgen, A.A. Torun and S. Ercisli, J. Food Comp. Anal., 23, 619 (2010).

20. A. Ismail, Z.M. Marjan and C.W. Foong, Food Chem., 87, 581 (2004).

21. Y.S. Velioglu, G. Mazza, L. Gao and B.D. Oomah, J. Agric. Food Chem., 46, 4113 (1998).

22. G.C. Yen, P.D. Duh and C.L. Tsai, J. Agric. Food Chem., 41, 67 (1993).

23. T.Y. Lim, Y.Y. Lim and C.M. Yule, Food Chem., 114, 594 (2009).

24. N. Andarwulan, R. Batari, D.A. Sandrasari, B. Bolling and H. Wijaya, Food Chem., 121, 1231 (2010).

25. M. Roche, C. Dufour, N. Mora and O. Dangles, Org. Biomol. Chem., 3, 423 (2005).

26. B. Tepe, O. Eminagaoglu, H.A. Akpulat and E. Aydin, Food Chem., 100, 985 (2007).

27. D. Villaño, M.S. Fernández-Pachón, M.L. Moyá and A.M. Troncoso, Talanta, 71, 230 (2007).

28. J.K. Moon and T. Shibamoto, J. Agric. Food Chem., 57, 1655 (2009).

29. T. Kulisic, A. Radonic, V. Katalinic and M. Milos, Food Chem., 85, 633 (2004).

30. M. Antolovich, P.D. Prenzler, E. Patsalides, S. McDonald and K. Robards, Analyst, 127, 183 (2002).

31. L.L. Stookey, Anal. Chem., 42, 779 (1970).

32. İ. Gülçin, I.G. Sat, S. Beydemir, M. Elmastas and Ö.I. Küfrevioglu, Food Chem., 87, 393 (2004).

33. T. Wang, R. Jónsdóttir and G. Ólafsdóttir, Food Chem., 116, 240 (2009).

34. N. Mohd-Esa, F.S Hern, A. Ismail and C.L. Yee, Food Chem., 122, 1055 (2010).

35. M. Hassas-Roudsari, P.R. Chang, R.B. Pegg and R.T. Tyler, Food Chem., 114, 717 (2009). 